\title{
SERUM BIOCHEMISTRY IN HYSTRICOMORPHA: AGOUTI (Dasyprocta prymnolopha) DURING PREGNANCY
}

\author{
BIOQUÍMICA SÉRICA EM HYSTRICOMORPHA: CUTIA (Dasyprocta prymnolopha, \\ WAGLER, 1831) DURANTE O PERÍODO GESTACIONAL
}

\author{
Maria Acelina Martins de CARVALHO ${ }^{1}$; Dayseanny de Oliveira BEZERRA ${ }^{2}$; \\ Camila Arrivabene NEVES ${ }^{2}$; Maíra Soares FERRAZ ${ }^{3}$; Yulla Klinger Pereira de CARVALHO ${ }^{4}$; \\ Antônio Augusto N. MACHADO JÚNIOR ${ }^{5}$; Aírton Mendes CONDE JÚNIOR ${ }^{3}$; \\ Gerson Tavares PESSOA ${ }^{1}$; Hatawa Melo de ALMEIDA ${ }^{5}$; Matheus Levi T. FEITOSA ${ }^{1}$; \\ Eunice Anita M. FORTES ${ }^{3}$
}

1. Department of Veterinary Morphophysiology, Federal University of Piauí Teresina, PI, Brazil; 2. Post-graduate student of Animal Science Program, Federal University of Piauí, PI, Brazil; 3. Department of Morphology, Federal University of Piauí, Teresina, PI, Brazil; 4. Post-graduate student of RENORBIO Program, Federal University of Piauí, PI, Brazil; 5. Department of Animal Science, Federal University of Piauí, Bom Jesus, PI, Brazil

\begin{abstract}
The aim of this estudy was to establish the levels of serum total protein, albumin, globulin, alanine aminotransferase (ALT), aspartate aminotransferase (AST), calcium, phosphorus, urea, creatinine, bilirubin and glucose during pregnancy in agoutis. Animals: Twelve pregnant agouti from the Center for the Study and Preservation of Wild Animals (CSPWA) of the Federal University of Piauí (UFPI) were used in this research. After identification of the estrus, the day of the coverage was confirmed by means of vaginal cytology with the visualization of spermatozoa (day zero) and confirmation of pregnancy by ultrasonographic examination after 15 days. Blood samples were collected by lateral saphenous vein puncture after physical restraint, every 10 days until the end of pregnancy, for biochemical analyzes. A completely randomized experimental design was used and the means compared by the Duncan test at 5\% probability using the SAS (Statistical Analysis System). The results of the biochemical analysis of total protein, albumin, globulin, urea, creatinine, calcium, phosphorus, serum ALT, glucose, AST, total bilirubin, direct bilirubin and indirect bilirubin in pregnant agouti (Dasyprocta prymnolopha) did not differ when compared to nonpregnant females. The serum biochemical levels during pregnancy in agoutis, except for calcium and phosphorus, were unchanged compared to those found in the non-pregnant adult animal, as occurs in other species. The changes during pregnancy reflect the physiology and biology of wild species, elucidating information about the biochemical parameters during pregnancy, thus characterizing the animal as a benchmark for comparisons with other species, extolling its importance both for nature conservation and production in capivity.
\end{abstract}

KEYWORDS: Biochemical; Dasyprocta prymnolopha; Gestation; Serum.

\section{INTRODUCTION}

The agouti (Dasyprocta $s p$ ) is a medium sized mamaly wild rodent, and has gestational period of 103 days (FORTES et al., 2013; LANGE; SCHMIDTH, 2007). This animal is being a rich source of protein and hunting target in the region, but is not on the list of endangered animals (BRASIL, 2016). In this way, its production in captivity is expanding, since several research groups are developing studies on its morphology, ultrasonographic and echocardiographic evaluation, as well as a biological model for alternative treatments of chronic diseases (CABRAL et al., 2012 ; CARVALHO et al., 2015 ; DINIZ et al., 2013 ; FORTES et al., 2013; SILVA et al. 2014 ; SOUSA et al., 2013). Blood is responsible for transporting and micronutrient elements related to metabolism and thus its analysis reflects the physiological situation of individual. Knowledge about the biochemical parameters in wildlife is important to standardize data, due to the paucity of research and form references to elucidate diseases and contribute to management in captivity (BRITO et al., 2006; KERR, 2003). This information during pregnancy is even rarer, and these data are of relevant importance to monitor and prevent metabolic disorders that may occur during this period. Since the biochemical parameters in the gestational phase are altered, differing from the parameters found in non-pregnant women, mainly because they are influenced by the fetal development, which requires greater energetic demand of the maternal part (FEIJO et al., 2014).

The blood proteins, including albumin and globulin, have different functions in the body such as the maintenance of osmotic pressure and blood viscosity, transport of nutrients, metabolites, hormones and excretion products, blood $\mathrm{pH}$ regulation and participation in blood clotting 
(THRALL et al., 2007). Alanine aminotransferase (ALT) is a specific enzyme and is distributed throughout the body, liver, skeletal muscle and heart, which indicates a disease and renal or muscle lesions (KERR, 2003).

Minerals such as calcium and phosphorus are structural components of tissues, And are enough required in the final third of gestation for bone growth, tissue development, and hormonal adaptations of the fetus, and for milk production. Calcium plays an important role in the transmission at the neuromuscular junction and impulse propagation muscle contraction, besides being the major component of bone. Calcium deficiency during the gestational period is linked to hypertensive pathology and may affect the bone mineral density of the fetus, in addition to the risk of triggering a preterm delivery (HARK ; CATALANO, 2012).

Urea is analyzed in relation to the level of dietary protein and kidney function. Creatinine, as urea, is a nitrogen degradation product, but it is produced by the endogenous metabolism and is not altered by the animal's diet (KERR, 2003; THRALL et al., 2007). Serum creatinine is excreted only by the kidneys, since it is not reused or reabsorbed by the body, ie, high levels indicate deficiency in kidney function (ARAÚJO et al., 2009). Among various metabolites used as fuel for oxidized respiratory glucose is considered the most important. It is vital to the metabolism of the brain, milk, and blood levels can indicate flaws in homeostase (LANGE; SCHMIDTH, 2007).

Aspartate aminotransferase (AST) is an enzyme that is found in the cytoplasm and mitochondria of skeletal muscle tissue, heart and liver cells. When there is damage to these tissues, these isoenzymes are released from the cytoplasm when the injury is mild, or from the mitochondria, when the lesion is more severe. However, its determination is usually used as a routine method to determine general cell necrosis (MOSS ; HANDERSON, 1998). And its activity increases in acute or chronic liver injury in all domestic species (HUANG et al., 2006). Bilirubin is found in plasma by degradation of old erythrocytes by the reticuloendothelial system, especially in the spleen or is derived from the degradation of myoglobin, cytochromes and the immature erythrocytes in bone marrow. The sum of the direct and indirect bilirubins levels indicates total bilirubin (LANGE; SCHMIDTH, 2007).

The objective of the present research was to establish the levels of serum total protein, albumin, globulin, alanine aminotransferase (ALT), aspartate aminotransferase (AST), calcium, phosphorus, urea, creatinine, bilirubin and glucose during pregnancy in agoutis.

\section{MATERIAL AND METHODS}

Twelve female agoutis (Dasyprocta prymnolopha) were used from the Center for Study and Preservation of Wild Animals - NEPAS (IBAMA, No. 02/08-618) of the Federal University of Piauí (UFPI ) after approval by the Ethics Committee on Animal Experiments (EAEC) UFPI No. 039/2010 and Authorization System and Biodiversity Information - SISBIO No. 24034-1.

The animals were fed with commercial feed, corn, fruit and water ad libitum. Eight agoutis were used for analysis of total protein, albumin, globulin, alanine aminotransferase (ALT), calcium, phosphorus, urea, creatinine, and four agoutis were used to evaluate glucose, aspartate aminotransferase (AST), total bilirubin, direct and indirect. The animals/agoutis were divided in groups of four females for one male. The estrus cycle was accompained by vaginal cytology and the day of mating (Day zero of pregnancy) was determined by sperm presence on the smears. The pregnancy was confirmed by ultrasound (Digital ultrassonic diagnostic imaging system Mindray, model: DP2200 Vet, microconvex transducer $6.5 \mathrm{MHz}$ ) about 15 days after determining day zero. After physical restraint, the animals were submited to collected of blood by saphenous lateral venipuncture every 10 days, from the beginning to the end of pregnancy, with the aid of $3 \mathrm{~mL}$ syringe and hypodermic needle $21 \mathrm{G}$.

Blood samples without anticoagulant were centrifuged at $2000 \mathrm{rpm}$ for fifteen minutes to obtain serum. The serum samples were transferred to microtubes, identified and kept frozen at $-20{ }^{\circ} \mathrm{C}$ until biochemical analysis. The samples were processed at the University Veterinary Hospital, Center for Agricultural Sciences/UFPI. Commercial kits (Labtest (B)were used to perform the biochemical tests and the analytes were read on a spectrophotometer (Tecnal model Bel 1105).

Statistical data were evaluated by analysis of variance for a completely randomized design and the means were compared by the Duncan test at 5\% probability using SAS (Statistical Analysis System).

\section{RESULTS}

The results of the biochemical analyses of total protein, albumin, globulin, urea, creatinine, calcium, phosphorus, serum ALT (Figure 1;Tables 1 
and 2) glucose (Figure 2, aspartate aminotransferase (AST) (Figure 3), total bilirubin, direct bilirubin and indirect bilirubin (Figure 4; Table 3) of pregnant agouti (Dasyprocta prymnolopha) showed no difference compared to nonpregnant females.

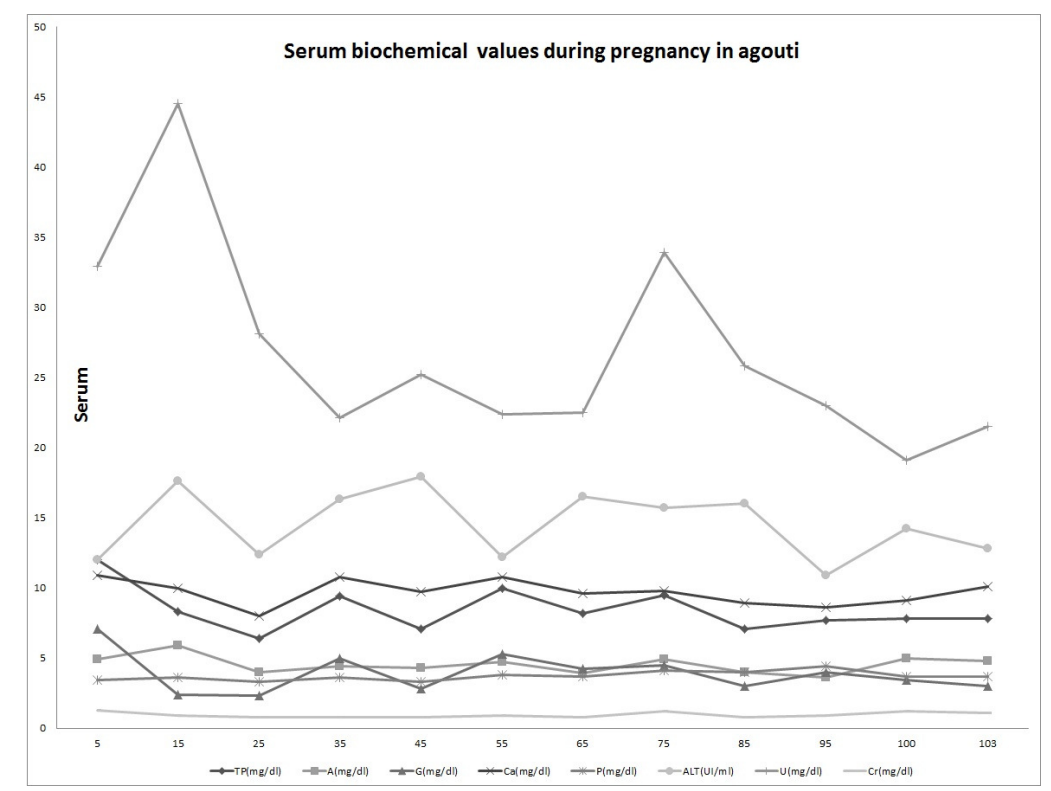

Figure 1. Serum biochemical profile of total protein (TP), albumin (A), globulin $(\mathrm{G})$, calcium $(\mathrm{Ca})$, phosphorus $(\mathrm{P})$, alanine aminotransferase (ALT), urea $(\mathrm{U})$ and creatinine $(\mathrm{Cr})$ in agouti (Dasyprocta prymnolopha) during the pregnancy.

Table 1. Serum biochemical profile in agouti (Dasyprocta prymnolopha) during the pregnancy.

\begin{tabular}{ccccc}
\hline D.P.C. & $\mathbf{T P}(\mathbf{m g} / \mathbf{d L})$ & $\mathbf{A}(\mathbf{m g} / \mathbf{d L})$ & $\mathbf{G}(\mathbf{m g} / \mathbf{d L})$ & $\mathbf{C a}(\mathbf{m g} / \mathbf{d L})$ \\
\hline $\mathbf{5}$ & $12.0 \pm 5.27 \mathrm{a}$ & $4.9 \pm 0.89 \mathrm{ab}$ & $7.1 \pm 4.40 \mathrm{a}$ & $10.9 \pm 3.18 \mathrm{a}$ \\
$\mathbf{1 5}$ & $8.3 \pm 4.74 \mathrm{~b}$ & $5.9 \pm 1.40 \mathrm{a}$ & $2.4 \pm 3.46 \mathrm{~b}$ & $10.0 \pm 3.81 \mathrm{a}$ \\
$\mathbf{2 5}$ & $6.4 \pm 0.57 \mathrm{~b}$ & $4.0 \pm 1.26 \mathrm{ab}$ & $2.3 \pm 0.83 \mathrm{~b}$ & $8.0 \pm 1.23 \mathrm{a}$ \\
$\mathbf{3 5}$ & $9.4 \pm 2.62 \mathrm{ab}$ & $4.4 \pm 1.65 \mathrm{ab}$ & $5.0 \pm 1.38 \mathrm{ab}$ & $10.8 \pm 2.10 \mathrm{a}$ \\
$\mathbf{4 5}$ & $7.1 \pm 2.36 \mathrm{ab}$ & $4.3 \pm 1.24 \mathrm{ab}$ & $2.8 \pm 1.87 \mathrm{~b}$ & $9.7 \pm 1.53 \mathrm{a}$ \\
$\mathbf{5 5}$ & $10.0 \pm 3.23 \mathrm{ab}$ & $4.7 \pm 1.81 \mathrm{ab}$ & $5.3 \pm 4.06 \mathrm{ab}$ & $10.8 \pm 1.87 \mathrm{a}$ \\
$\mathbf{6 5}$ & $8.2 \pm 2.12 \mathrm{~b}$ & $3.9 \pm 1.13 \mathrm{ab}$ & $4.2 \pm 2.30 \mathrm{ab}$ & $9.6 \pm 1.13 \mathrm{a}$ \\
$\mathbf{7 5}$ & $9.5 \pm 3.07 \mathrm{ab}$ & $4.9 \pm 1.99 \mathrm{ab}$ & $4.5 \pm 2.74 \mathrm{ab}$ & $9.8 \pm 1.9 \mathrm{a}$ \\
$\mathbf{8 5}$ & $7.1 \pm 1.78 \mathrm{~b}$ & $4.0 \pm 0.50 \mathrm{ab}$ & $3.0 \pm 1.51 \mathrm{~b}$ & $8.9 \pm 2.35 \mathrm{a}$ \\
$\mathbf{9 5}$ & $7.7 \pm 1.82 \mathrm{~b}$ & $3.6 \pm 1.07 \mathrm{~b}$ & $4.0 \pm 1.84 \mathrm{ab}$ & $8.6 \pm 1.28 \mathrm{a}$ \\
$\mathbf{1 0 0}$ & $7.8 \pm 2.59 \mathrm{~b}$ & $5.0 \pm 2.08 \mathrm{ab}$ & $3.4 \pm 1.04 \mathrm{~b}$ & $9.1 \pm 1.86 \mathrm{a}$ \\
$\mathbf{1 0 3}$ & $7.8 \pm 1.17 \mathrm{~b}$ & $4.8 \pm 1.04 \mathrm{ab}$ & $3.0 \pm 0.24 \mathrm{~b}$ & $10.1 \pm 0.92 \mathrm{a}$ \\
\hline
\end{tabular}

D.P.C, Days post coitum; TP, total protein; A, albumin; G, globulin and Ca, calcium. Means followed by the same letter do not differ significantly by Duncan's test $(P<0,05)$. 
Table 2. Serum biochemical profile during the pregnancy in agouti (Dasyprocta prymnolopha).

\begin{tabular}{ccccc}
\hline D.P.C. & P(mg/dL) & $\mathbf{A L T}(\mathbf{U I} / \mathbf{m L})$ & $\mathbf{U}(\mathbf{m g} / \mathbf{d L})$ & $\mathbf{C r}(\mathbf{m g} / \mathbf{d L})$ \\
\hline $\mathbf{5}$ & $3.4 \pm 0.90 \mathrm{a}$ & $12.0 \pm 5.27 \mathrm{a}$ & $32.9 \pm 21.78 \mathrm{ab}$ & $1.25 \pm 0.62 \mathrm{ab}$ \\
$\mathbf{1 5}$ & $3.6 \pm 0.70 \mathrm{a}$ & $17.6 \pm 12.35 \mathrm{ab}$ & $44.5 \pm 21.23 \mathrm{a}$ & $0.9 \pm 0.41 \mathrm{ab}$ \\
$\mathbf{2 5}$ & $3.3 \pm 0.76 \mathrm{a}$ & $12.4 \pm 3.61 \mathrm{~b}$ & $28.1 \pm 14.17 \mathrm{ab}$ & $0.8 \pm 0.38 \mathrm{ab}$ \\
$\mathbf{3 5}$ & $3.6 \pm 0.86 \mathrm{a}$ & $16.3 \pm 4.15 \mathrm{ab}$ & $22.1 \pm 10.32 \mathrm{~b}$ & $0.8 \pm 0.14 \mathrm{ab}$ \\
$\mathbf{4 5}$ & $3.3 \pm 0.80 \mathrm{a}$ & $17.9 \pm 11.06 \mathrm{ab}$ & $25.2 \pm 11.09 \mathrm{~b}$ & $0.8 \pm 0.15 \mathrm{ab}$ \\
$\mathbf{5 5}$ & $3.8 \pm 0.97 \mathrm{a}$ & $12.2 \pm 5.30 \mathrm{~b}$ & $22.4 \pm 9.68 \mathrm{~b}$ & $0.9 \pm 0.17 \mathrm{ab}$ \\
$\mathbf{6 5}$ & $3.7 \pm 0.48 \mathrm{a}$ & $16.5 \pm 9.92 \mathrm{ab}$ & $22.5 \pm 12.91 \mathrm{~b}$ & $0.8 \pm 0.11 \mathrm{ab}$ \\
$\mathbf{7 5}$ & $4.1 \pm 1.27 \mathrm{a}$ & $15.7 \pm 3.4 \mathrm{~b}$ & $33.9 \pm 17.46 \mathrm{a}$ & $1.2 \pm 0.4 \mathrm{ab}$ \\
$\mathbf{8 5}$ & $4.0 \pm 1.26 \mathrm{a}$ & $16.0 \pm 5.31 \mathrm{ab}$ & $25.8 \pm 8.38 \mathrm{~b}$ & $0.8 \pm 0.04 \mathrm{~b}$ \\
$\mathbf{9 5}$ & $4.4 \pm 1.24 \mathrm{a}$ & $10.9 \pm 2.63 \mathrm{~b}$ & $23.0 \pm 5.13 \mathrm{~b}$ & $0.9 \pm 0.04 \mathrm{ab}$ \\
$\mathbf{1 0 0}$ & $3.7 \pm 0.64 \mathrm{a}$ & $14.2 \pm 7.93 \mathrm{~b}$ & $19.1 \pm 14.96 \mathrm{~b}$ & $1.2 \pm 0.27 \mathrm{a}$ \\
$\mathbf{1 0 3}$ & $3.7 \pm 0.64 \mathrm{a}$ & $12.8 \pm 4.15 \mathrm{~b}$ & $21.5 \pm 7.55 \mathrm{~b}$ & $1.10 .06 \mathrm{ab}$ \\
\hline
\end{tabular}

D.P.C, Days post coitum; P, phosphorus, ALT, alanine aminotransferase; U, ureia; Cr, creatinine. Means followed by the same letter do not differ significantly by Duncan's test $(P<0,05)$.

Table 3. Serum biochemical profile in agouti (Dasyprocta prymnolopha) during the pregnancy.

\begin{tabular}{cccccc}
\hline D.P.C. & $\mathbf{G L}(\mathbf{m g} / \mathbf{d L})$ & $\mathbf{A S T}(\mathbf{U I} / \mathbf{L})$ & $\mathbf{T B}(\mathbf{m g} / \mathbf{d L})$ & $\mathbf{D B}(\mathbf{m g} / \mathbf{d L})$ & $\mathbf{I B}(\mathbf{m g} / \mathbf{d L})$ \\
\hline $\mathbf{0}$ & $173 \pm 9.93 \mathrm{a}$ & $9.60 \pm 0.00 \mathrm{a}$ & $0.40 \pm 0.02 \mathrm{~b}$ & $0.10 \pm 0.02 \mathrm{a}$ & $0.30 \pm 0.04 \mathrm{a}$ \\
$\mathbf{1 0}$ & $143.1 \pm 18.71 \mathrm{a}$ & $9.60 \pm 2.92 \mathrm{a}$ & $0.50 \pm 0.15 \mathrm{ab}$ & $0.10 \pm 0.11 \mathrm{a}$ & $0.30 \pm 0.17 \mathrm{a}$ \\
$\mathbf{2 0}$ & $157.2 \pm 19.17 \mathrm{a}$ & $9.15 \pm 2.01 \mathrm{a}$ & $0.40 \pm 0.05 \mathrm{~b}$ & $0.10 \pm 0.06 \mathrm{a}$ & $0.30 \pm 0.02 \mathrm{a}$ \\
$\mathbf{3 0}$ & $156.75 \pm 16.57 \mathrm{a}$ & $8.65 \pm 3.37 \mathrm{a}$ & $0.47 \pm 0.18 \mathrm{ab}$ & $0.13 \pm 0.06 \mathrm{a}$ & $0.34 \pm 0.12 \mathrm{a}$ \\
$\mathbf{4 0}$ & $169.2 \pm 38.79 \mathrm{a}$ & $10.60 \pm 6.75 \mathrm{a}$ & $0.60 \pm 0.30 \mathrm{ab}$ & $0.20 \pm 0.01 \mathrm{a}$ & $0.40 \pm 0.29 \mathrm{a}$ \\
$\mathbf{5 0}$ & $175.65 \pm 23.28 \mathrm{a}$ & $10.55 \pm 2.29 \mathrm{a}$ & $0.50 \pm 0.21 \mathrm{ab}$ & $0.15 \pm 0.06 \mathrm{a}$ & $0.35 \pm 0.18 \mathrm{a}$ \\
$\mathbf{6 0}$ & $170.35 \pm 52.79 \mathrm{a}$ & $9.60 \pm 5.06 \mathrm{a}$ & $0.64 \pm 0.09 \mathrm{ab}$ & $0.20 \pm 0.05 \mathrm{a}$ & $0.40 \pm 0.10 \mathrm{a}$ \\
$\mathbf{7 0}$ & $171.2 \pm 27.73 \mathrm{a}$ & $8.70 \pm 0.95 \mathrm{a}$ & $0.50 \pm 0.13 \mathrm{ab}$ & $0.22 \pm 0.07 \mathrm{a}$ & $0.40 \pm 0.14 \mathrm{a}$ \\
$\mathbf{8 0}$ & $178.6 \pm 64.73 \mathrm{a}$ & $8.70 \pm 0.50 \mathrm{a}$ & $0.59 \pm 0.13 \mathrm{ab}$ & $0.21 \pm 0.09 \mathrm{a}$ & $0.42 \pm 0.11 \mathrm{a}$ \\
$\mathbf{9 0}$ & $180.6 \pm 17.47 \mathrm{a}$ & $7.00 \pm 2.29 \mathrm{a}$ & $0.71 \pm 0.17 \mathrm{ab}$ & $0.20 \pm 0.05 \mathrm{a}$ & $0.43 \pm 0.18 \mathrm{a}$ \\
$\mathbf{1 0 0}$ & $173.25 \pm 20.14 \mathrm{a}$ & $8.70 \pm 1.23 \mathrm{a}$ & $0.69 \pm 0.33 \mathrm{a}$ & $0.14 \pm 0.15 \mathrm{a}$ & $0.56 \pm 0.18 \mathrm{a}$ \\
\hline
\end{tabular}

D.P.C, Days post coitum; GL, glucose; AST, aspartate aminotransferase; TB, total bilirubin; DB, direct bilirubin; IB, indirect bilirubin. Means followed by the same letter do not differ significantly by Duncan's test $(P<0,05)$.

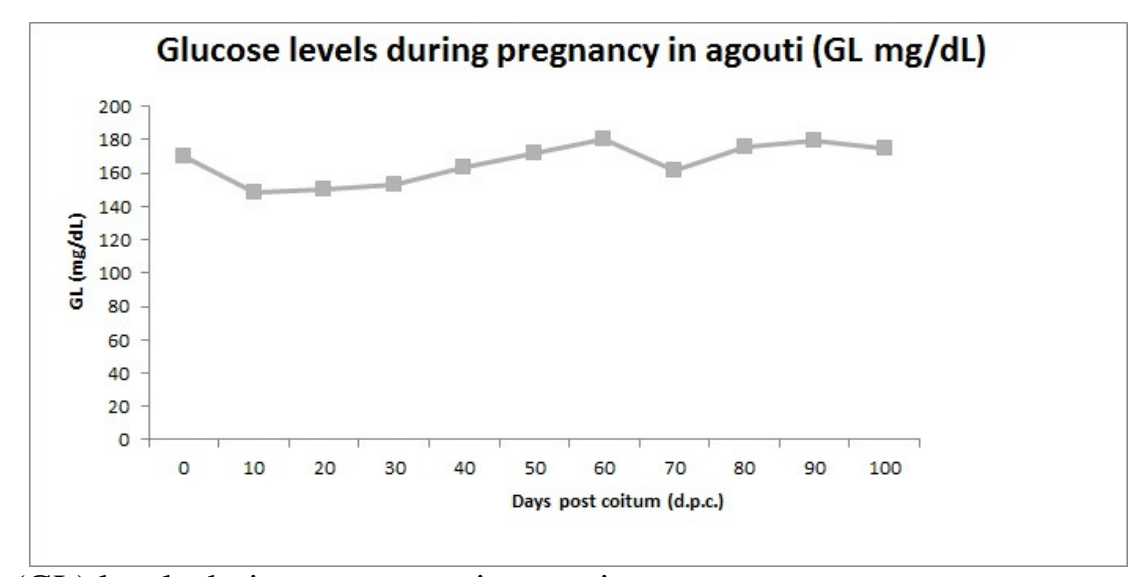

Figure 2. Glucose (GL) levels during pregnancy in agouti. 


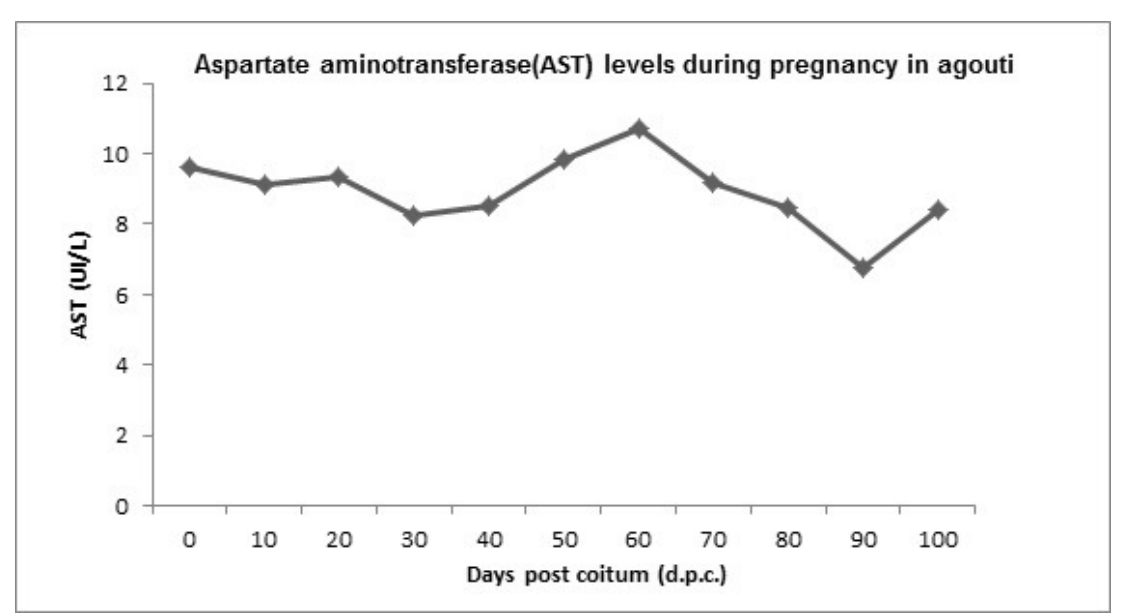

Figure 3. Aspartate aminotransferase (AST) levels during pregnancy in agouti.

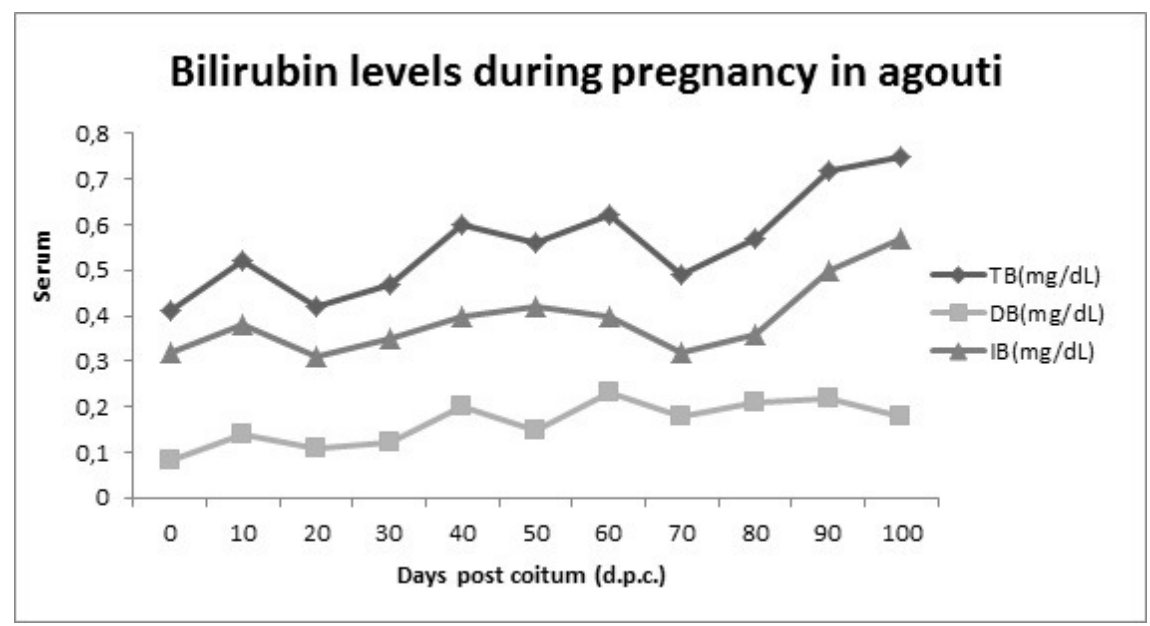

Figure 4. Bilirubin levels during pregnancy,Total Bilirubin (TB), Direct Bilirubin (DB) and Indirect Bilirubin (IB).

Serum total protein, essential for the structural development in the embryo, behaves differently during pregnancy. There is an increase in the initial period until 35 days post coitum (d.p.c.), and at the end of pregnancy, the maternal concentrations of serum proteins decrease.

Albumin values up to 15 d.p.c. increased considerably although there was a decrease in serum in the middle period, followed by significant increase in albumin in late pregnancy. The peak globulin was given until 5 d.p.c. (Table 1). After

The serum creatinine levels increased only at the end of the pregnancy, remaining at lower levels in the other phases. Glucose serum levels observed in the present research were superior to baseline and did not change during the pregnancy in agoutis.

The values obtained for AST were lower than in non pregnant agouti and during the gestational periods the levels were constant, with no statistically significant difference. this initial stage, there was a decrease followed by an increase at the end of pregnancy.

The serum ALT, also increased in the initial phase and then dropped in the middle period and increased again in late pregnancy. The amounts of calcium and phosphorus during pregnancy were constant with no significant differences throughout the pregnancy. As for urea during pregnancy, there was an increase only in early pregnancy, and these values decreased in the middle and late periods.

The values of indirect and total bilirubin levels decreased or were low during the first two thirds of gestation but increased near to parturition. Direct bilirubin decreased throughout the period in relation to the values for non pregnant agoutis. There was no significant difference for total bilirubin with lower values in the early and middle thirds and higher levels near parturition. 


\section{DISCUSSION}

During pregnancy factors such as diet, embryonic state and fetal development influence serum biochemistry and micronutrient electrolytes (FEIJO et al., 2014). Analyzing the results (Figure $1,2,3$ and 4) it can be inferred that the requirements of the agouti embryo in the middle period of pregnancy (25-65 d.p.c.) increased because of embryonic structure development. Fetal growth and maturity occurred between 75 and 100 d.p.c., with increased weight and size, including the development of facial and body features (FORTES et al., 2013). Maternal levels of these elements decreased in this period. Thus when the requirement of the fetus was higher the expression was lower in the maternal peripheral blood.

The increase in total protein in the initial period when compared to non-pregnant agouti (7.43 $\pm 0.77 \mathrm{~g} / \mathrm{dL}$ ) may have been due to the fact that the maternal body was preparing for the highest embryo requirement (LANGE; SCHMIDTH, 2007). Another factor is related to food, as this is rich in protein, and it is known that the total protein in serum is directly related to nutrition and liver function (BRITO et al., 2006). In the middle period of pregnancy the maternal concentrations of serum proteins decrease due to fetal growth and especially because of the use of amino acids from the mother for fetal protein synthesis in muscle, similar to that in, cats, rats and pregnant mares (LANGE; SCHMIDTH, 2007; ŞiMŞEK, et al., 2015; SILVA et al., 2008; PICCIONE et al., 2009; OROZC et al., 2007).

Albumin values found in agoutis until 15 d.p.c. increased considerably (Figure 1) above the results observed in non-pregnant adult agoutis (3.84 $\pm 0.32 \mathrm{~g} / \mathrm{dL}$ ) (LANGE; SCHMIDTH, 2007). The decrease in the middle third followed by significant increase in albumin in late pregnancy provided the increased energy requirements for fetal growth (PICCIONE et al, 2009). These results are similiar to studies on pregnant ewes, where the largest variations in blood metabolites occur in late pregnancy, which corresponds to times of greater metabolic demand (KERR, 2003).

The peak globulin was given until 5 d.p.c. (Figure 1) resembling the benchmarks $(3.59 \pm 0.22$ $\mathrm{g} / \mathrm{dL}$ ) for non-pregnant animals (LANGE; SCHMIDTH, 2007). An increase was observed in bitches in circulating globulin in the first third of pregnancy due to the need for greater supply to deliver proteins and antibody synthesis for lactation (VANNUCCHI et al., 2016).
Serum plasma enzyme ALT increases when there is greater production, increased release or greater clearance of the enzyme. Besides the liver, the rodents have ALT activity in the intestines, kidneys, heart, skeletal muscle, brain, pancreas and tegument (BRITO et al, 2006). Therefore, the ALT levels will only be changed when there is severe liver cell damage or muscle injury (KERR, 2003). The changes during pregnancy in agouti were defined based on reference values in non-pregnant animals $(20 \pm 4.6 \mathrm{IU} / \mathrm{mL}$ for Dasyprocta prymnolopha (KANEKO et al., 1997) and $28.08 \pm$ $15.53 \mathrm{IU} / \mathrm{mL}$ for Dasyprocta sp (RIBEIRO et al., 2008).

The calcium found throughout pregnancy in agouti did not change compared to non-pregnant animals $(7.62 \pm 2: 59 \mathrm{mg} / \mathrm{dL})$ (RIBEIRO et al., 2008). These results corroborated the fact that changes in calcium levels, such as hypercalcemia, only occur when there is increased serum albumin or excessive venous stasis during sample harvesting (KERR, 2003).

The values of phosphorus levels in nonpregnant agoutis reported in the literature are $3.91 \pm 1.41 \mathrm{mg} / \mathrm{dL}$ (RIBEIRO et al., 2008). In pregnant females, higher values of electrolytes may occur due to greater demand for fetus training (LANGE; SCHMIDTH, 2007), as in sheep, where it was observed that in the end of gestation, the concentration of phosphorus was close to the lower limit for the species indicating greater expenditure in these periods (BRITO et al., 2006). However, in the agouti, there was no change in the calcium and phosphorus levels (Figure 1), which can be attributed to the use of different measurement techniques and sample preservation, and even the food restraint, the handling, the forms of containment and the methodologies used in determining serum concentrations.

As to the urea values in the pregnant agoutis, they were equal to the normal baseline urea observed in non-pregnant agouti $(2.57 \pm 6.34$ mg/dL) (LANGE; SCHMIDTH, 2007). The high levels of urea in early pregnancy can be attributed to increased protein catabolism, as well as the high energy requirement, as observed in pregnant sheep (PICCIONE et al., 2009). The results of urea values may have been influenced by the type of diet, liver function, gastrointestinal absorption and hydration status (BRITO et al., 2006).

The creatinina values observed in pregnant agoutis were similar to non-pregnant $D$. prymnolopha values $(1.4 \pm 0.27 \mathrm{mg} / \mathrm{dL}$ ) (LANGE; SCHMIDTH, 2007). The normal values during the early and middle periods of gestation are due to 
decreased metabolic rate, as occurrs in pregnant mares, since creatinine is the final product of phosphocreatine breakdown. The amount of creatinine formed depends on the total body creatine content, which in turn depends on the food intake of creatine synthesis rate and muscle mass (PICCIONE et al., 2009).

Glucose serum levels found in the pregnant agoutis were greater than the values reported in nonpregnant agoutis (123.1 $\mathrm{mg} / \mathrm{dL})$ (LANGE; SCHMIDTH, 2007). This increase in glucose levels throughout the gestational period may be related to the large energy demand of pregnant agouti to form and maintain the fetus. Due to this condition in the captive production of this animal of that study there was food supplementation during this period, which may be related to this serum glucose increase in this phase. In rabbits the glucose serum levels fall near to parturition in the final third of pregnancy due to rapid fetal growth in the last weeks of pregnancy, and may even be related to the lactation peak, with the uptake of this metabolite by the mammary gland for lactose synthesis (HANEDA et al., 2010; MIZOGUCHI et al., 2010). The initial hypoglycemia in pregnant sheep is described as pregnancy toxemia (SANTOS et al., 2011) and this fact corroborates our study since during pregnancy in agoutis (Figure 2) no pathological changes were observed.

The values obtained for AST in pregnant agouti were lower than in non-pregnant $D$. leporina $(44.47 \pm 23.19 \mathrm{IU} / \mathrm{mL})$ and Dasyprocta prymnolopha $(20 \pm 4.6 \mathrm{IU} / \mathrm{mL})$ (LANGE; SCHMIDTH, 2007). During pregnancy the levels remained constant, with no statistically significant difference. The pregnant agouti (Figure 3) showed similar results quoted in the literature (WAHAB et al., 2016) that show a decrease in AST values at the end of pregnancy in habbits. In contrast, reduced AST was observed in the final third of pregnancy in mares (MILINKOVIC-TUR, 2005). This occurs because pregnancy and lactation are conditions in which metabolic activity in the body is increased, influencing variations in blood. One of the activities of aminotransferases in blood is to serve as catalyst for reactions that transform amino acids to carbohydrates (KANEKO et al., 1997).

The values of indirect and total bilirubin decreased during the first two thirds of gestation and increased a few days before birth, and direct bilirubin decreased throughout the period mentioned (Figure 4) compared to reference values for nonpregnant D. prymnolopha $(0.24 \pm 0.12 \mathrm{mg} / \mathrm{dL}$ for direct bilirubin, $0.37 \pm 0.06 \mathrm{mg} / \mathrm{dL}$ for indirect bilirubin and $0.62 \pm 0.14 \mathrm{mg} / \mathrm{dL}$ for total bilirubin) (LANGE; SCHMIDTH, 2007).

However, the statistical difference found within the gestational period can be explained by the fact that the determination of bilirubin total, direct and indirect, enables the diagnosis of disorders responsible for the development of jaundice in numerous species (KANEKO et al., 1997). The findings obtained in this research, i.e., decrease in serum bilirubin levels allow us to infer that there were no infections causing hemolytic or obstructive hepatobiliary (cholestasis) in agoutis. These values of decreased bilirubin are a condition that could be associated with increased fluid accumulation that occurs during pregnancy.

\section{CONCLUSIONs}

The determination of biochemical parameters during the gestation of agoutis was possible.

The serum biochemical levels changed during pregnancy in agoutis, except for calcium and phosphorus, when compared to non-pregnant animals, as occurs in other species.

The serum biochemistry in pregnant agouti undergoes changes according to the time of gestation, with the biggest changes in the initial and final phases of pregnancy.

The changes during pregnancy reflect the physiology and biology of wild species, elucidating information about the biochemical parameters during pregnancy, thus characterizing the animal as a benchmark for comparisons with other species, extolling its importance both for nature conservation and production.

\section{ACKNOWLEDGMENTS}

We thank the Conselho Nacional de Desenvolvimento Científico e Tecnológico-CNPq [Brazilian Technological and Scientific Development Council], for financial support (process no. 483247/2009-0 - Edital MCT/CNPq).

RESUMO: O estudo objetivou estabelecer os níveis séricos de proteínas totais, albumina, globulina, Alanina Aminotransferase (ALT), Aspartato Aminotransferase (AST), cálcio, fósforo, ureia, creatinina, bilirrubina e glicose durante a gestação em cutias. A pesquisa foi desenvolvida utilizando-se 12 cutias fêmeas criadas no Núcleo de Estudos, Produção e Preservação de Animais Silvestres da Universidade Federal do Piauí. Após a identificação do estro, o dia da 
cobertura foi confirmado por meio de citologia vaginal com a visualização de espermatozoides (dia zero) e confirmação da gestação por exame ultrassonográfico após 15 dias. Confirmada a gestação, foram coletados 03 mL de sangue mediante punção da veia pudenda interna, após contenção física, a cada 10 dias, até o final da gestação. Foi feita a análise de variância para um delineamento inteiramente casualizado com teste de Duncan para comparação das médias a $5 \%$ de probabilidade utilizando-se do programa estatístico SAS (Statistical Analysis System). Os resultados obtidos por meio da análise bioquímica de proteína total, albumina, globulina, ureia, creatinina, cálcio, fósforo, ALT séricas, glicose, aspartato aminotransferase (AST), bilirrubina total, bilirrubina direta e bilirrubina indireta de cutias gestantes (Dasyprocta prymnolopha) diferem de forma absoluta quando comparados a fêmeas não gestantes. Os níveis bioquímicos séricos durante a gestação em cutias, com exceção do cálcio, fósforo, sofrem alterações comparadas ao animal adulto não prenhe, como ocorre em outras espécies. Os níveis nas cutias gestantes sofrem alterações de acordo com o tempo de gestação, com maiores mudanças no período inicial e final da prenhez. As mudanças durante a gravidez refletem a fisiologia e a biologia da espécie silvestre, elucidando informações sobre os parâmetros bioquímicos durante a gestação, caracterizando o animal como referência para comparações com outras espécies, exaltando a importância tanto para sua conservação quanto para a sua produção em cativeiro.

PALAVRAS-CHAVE: Bioquímica. Dasyprocta prymnolopha. Gestação. Soro.

\section{REFERENCES}

ARAÚJO, P. B.; PEREIRA, D. D.; TEIXEIRA, M. N.; COELHO, M. C. O. C.; ALENCAR, S. P. Urinálise como instrumento auxiliar no diagnóstico de enfermidades em pequenos ruminantes. Revista de Medicina Veterinária. v. 3, p. 30-38, 2009.

BRITO, M. A.; GONZÁLEZ, F. D.; RIBEIRO, L. A. Composição do sangue e do leite em ovinos leiteiros do sul do Brasil: variações na gestação e na lactação. Ciência Rural, Santa Maria, v. 36, p. 942-948, 2006. https://doi.org/10.1590/S0103-84782006000300033

CABRAL, R. M.;FERRAZ, M. S.;RIZZO, M. S.;SOUSA, F. C. A.; RODRIGUES, N. M ; IBIAPINA, P.B.; AMBRÓSIO, C. E. ;CARVALHO, M. A. M. . Kidney Injury and Cell Therapy: Preclinical Study. Microscopy Research and Technique (Print), v. 75, p. 566-570, 2012 https://doi.org/10.1002/jemt.21092

CARVALHO, Y. K. P.;ARGOLO NETO, N. M.; AMBRÓSIO, C. E. ; OLIVEIRA, L. J. ;ROCHA, A. R.; SILVA, J. B. ; CARVALHO, M. A. M. ;ALVES, F. R. Isolation, expansion and differentiation of cellular progenitors obtained from dental pulp of agouti (Dasyprocta prymnolopha Wagler, 1831) cell progenitor from agouti dental pulp. Pesquisa Veterinária Brasileira (Impresso), v. 35, p. 590-598, 2015. https://doi.org/10.1590/S0100-736X2015000600018

DINIZ, A. N.; AMBRÓSIO, C. E.; SOUSA, J. M.; SOUSA, V. R.; CARVALHO, M. A. M.; NASCIMENTO, D. M.; ALVES, F. R. ; SOUSA JUNIOR, J. R. Thoracic and heart biometrics of non-anesthetized agouti (Dasyprocta primnolopha Wagler, 1831) measured on radiographic images. Pesquisa Veterinária Brasileira (Impresso), v. 33, p. 411-416, 2013. https://doi.org/10.1590/S0100-736X2013000300023

FAROOQ, U.; SAJJAD, S.; ANWAR M.; KHAN, B. N. Serum chemistry variables of Bengal tigers (Panthera tigris tigris) kept in various forms of captivity. Pakistan Veterinary Journal, v. 32, p. 283-285, 2012.

FEIJÓ, J. O.; PERAZZOLI, D.; SILVA, L. G. C.; ARAGÃO, R. B.; MARTINS, C. F.; PEREIRA, R. A.; FERREIRA, M. B.; DEL PINO, F. A. B.; RABASSA, V. R.; CORRÊA, M. N. Avaliação de parâmetros bioquímicos clínicos de ovelhas do grupo genético pantaneiro gestantes e não gestantes. Brazilian Journal of Veterinary Reserch and Animal Science, v. 51, p. 111-117, 2014. https://doi.org/10.11606/issn.23183659.v51i2p111-117 
FORTES, E. A. D. M.; FERRAZ, M. S.; BEZERRA, D. O.; JÚNIOR, A. M., CABRAL R. M.; SOUSA, F. D., ALMEIDA, H. M., PESSOA, G. T., MENEZES, D. J., GUERRA, S. P.; SAMPAIO, I. B.; ASSIS NETO, A. C., CARVALHO, M. A. M. Prenatal development of the agouti (Dasyprocta prymnolopha Wagler, 1831): External features and growth curves. Animal Reproduction Science, v. 140, p. 195-205, 2013. https://doi.org/10.1016/j.anireprosci.2013.06.021

HANEDA, R.; MIZOGUCHI, Y.; MATSUOKA, T.; MIZUGUCHI, H.; ENDOH, T.; FUKUDA, K.; ASANO, Y. Changes in blood parameters in pregnant Japanese White rabbits. The Journal of toxicological sciences, $v$. 35, p. 773-778, 2010. https://doi.org/10.2131/jts.35.773

HARK, L.; CATALANO, P. M. Nutritional Management During Pregnancy. In: Obsterics Normal and Problem Pregnancies. GAB-BE, S.; NIEBYL, J.; SIMPSON, J.; LANDON, M.; GALAN, H.; JAUNIAUX, E. et al. 6. ed. Philadelphia: Elsevier, 2012. https://doi.org/10.1016/b978-1-4377-1935-2.00007-7

HUANG, X.J.; CHOI, Y.K.; IM, H.S.; YARIMAGA, O.; YOON, E.; KIM, H.S. Aspartate aminotransferase (AST/GOT) and Alanine aminotransferase (ALT/GPT) detection techniques. Sensors, v. 6, p.756-782, 2006. https://doi.org/10.3390/s6070756

KANEKO, J. J.; HARVEY, J. W.; BRUSS, M. L. Clinical biochemistry of domestic animals. San Diego: Academic Press, p. 932, 1997.

KERR, M. G. Exames Laboratoriais em Medicina Veterinária: bioquímica clínica e hematologia. 2. ed. São Paulo: Roca, 2003.

LANGE, R. R.; SCHMIDT, E. M. Rodentia - Roedores Silvestres (Capivara, Cutia, Paca, Ouriço) In: CUBAS, Z. S.; SILVA, J. C. R.; CATÃO-DIAS, J. L. Tratado de Animais Selvagens. São Paulo: Roca, p. 475-491, 2007.

MILINKOVIC-TUR, S. Growth and nutrition in the horse. New York: Books and Company, p. 232, 2005.

BRASIL. Ministério do Meio Ambiente. Lista Nacional das Espécies da Fauna Brasileira Ameaçadas de Extinção. Disponível em: <http://www.mma.gov.br/biodiversidade/especies-ameacadas-de-extincao/faunaameacada>. Acesso em: 12 de dezembro de 2016.

OROZC, C. A. G.; MARTINS, C. B.; D’ ANGELIS, F. H. D. F.; Oliveira, J. V. D.; Lacerda-Neto, J. C. D. Hematological values and total protein of Brasileiro de Hipismo and Breton mares during pregnancy. Ciência Rural, v. 37, p. 1695-1700, 2007. https://doi.org/10.1590/S0103-84782007000600029

PICCIONE, G.; CAOLA, G.; GIANNETTO, C.; CAOLA, G.; GIANNETTO, C.; GRASSO, F.; RUNZO, S. C.; ZUMBO, A.; PENNISI, P. Selected biochemical serum parameters in ewes during pregnancy, postparturition, lactation and dry period. Animal Science Papers and Reports, v. 27, p. 321-333, 2009.

RIBEIRO, E. E.; BATISTA, M. C. S.; CARVALHO, M. A. M.; SILVA, J. A. Níveis iônicos e enzimáticos de cutias (Dasyprocta sp) hígidas, criadas em cativeiro, influência do sexo e da idade. Arquivo Brasileiro de Medicina Veterinária e Zootecnia, v. 60, p. 651-655, 2008. https://doi.org/10.1590/S010209352008000300019

SANTOS, F. C. O.; MENDONÇA, C. L.; SILVA FILHO, A. P.; CARVALHO, C. D. C.; SOARES, P. C.; AFONSO, J. A. B. Indicadores bioquímicos e hormonais de casos naturais de toxemia da prenhez em ovelhas. Pesquisa Veterinária Brasileira, v. 31, 2011.

SILVA, A. B. S. ; SANTOS, T. M. V. ; CARVALHO, M. A. M. ; GUERRA, S. P. L. ; RIZZO, M. S. ; ARAUJO, W. R. ; TORRES, C. B. B. ; CONDE JÚNIOR, A. M.. Morfologia da laringe de cutia (Dasyprocta sp.). Pesquisa Veterinária Brasileira (Impresso), v. 34, p. 593-598, 2014. https://doi.org/10.1590/S0100736X2014000600015 
SILVA, L. F.; LIMA, D. F.; NASCIMENTO, C. B. S. Efeitos da farinha de algaroba (Prosopis juliflora) durante as fases de gestação e lactação em ratas Wistar. Acta Scientiarum, v. 25, p. 459-465, 2008.

ŞIMŞEK, Ö.; ARIKAN, Ş.; CINAR, M. Reference values for selected hematological and biochemical blood parameters from prepregnancy to advanced gestation in Angora cats. Turkish Journal of Veterinary and Animal Sciences, v. 39, p. 29-33, 2015.

SOUSA, F. C. A. ; FORTES, E. A. M. ; FERRAZ, M.S.; MACHADO JÚNIOR, A. A. N. ; MENEZES, D. J. A. ; CARVALHO, M. A. M. Pregnancy in Hytricomorpha: Gestacional age and embrryonic-fetal development of agouti (Dasyprocta prymnolopha, Wagler 1831) estimatede by ultrasonograpy. Theriogenology, v. 78, p. 1278-1285, 2013. https://doi.org/10.1016/j.theriogenology.2012.05.023

THRALL, M. A.; BAKER, D. C.; CAMPBELL, T. W. Hematologia e Bioquímica Clínica Veterinária. Roca: São Paulo, p. 433-447, 2007.

VANNUCCHI, C. I.; LÚCIO, C. F.; REGAZZI, F. M.; SR ANGRIMANI, D.; BRITO, M. M.; ABREU, R. A. Plasmatic protein profile of pregnant and non-pregnant bitches. Pesquisa Veterinária Brasileira, v. 36, p.781786, 2016. https://doi.org/10.1590/S0100-736X2016000800017

WAHAB, A.; KHAN, H.; AHMAD, S.; QURESHI, M. S.; MUHAMMAD, Y.; KHAN, S.; SHAH, M. K. Biochemical Profile of Local Rabbits (Oryctolagus cuniculus) During Successful Pregnancy Under Backyard Production System. Pakistan Journal of Zoology, v. 48, p.625-630, 2016. 